\title{
Investigation on Biomass Briquette as Energy Source from Waste Leaf Cerbera Manghas
}

\author{
Willyanto Anggono, ${ }^{1, a}$, Fandi D. Suprianto ${ }^{2, b}$, Sutrisno ${ }^{3, c}$, Andreas W. Kasrun ${ }^{4, d}$ \\ ${ }^{1,2,3,4}$ Mechanical Engineering Department, Petra Christian University, Surabaya, East Java, Indonesia \\ ${ }_{1,2,3,4}$ Centre for Sustainable Energy Studies, Petra Christian University, Surabaya, East Java, Indonesia \\ ${ }^{a}$ willy@petra.ac.id, ${ }^{b}$ fandi@petra.ac.id, Ctengsutrisno@petra.ac.id, dandreas94_kun@yahoo.com
}

\begin{abstract}
Indonesia is a tropical country and has abundant varieties of plants but has not been utilized to the fullest. One of the plants that are often encountered in the community is Cerbera manghas. Cerbera manghas is known as one of the trees that have solid roots; thus, it is widely used for adding greenery both on the roadside and the residential areas of Surabaya. Although beneficial for shade and the reduction of air pollution in urban areas, waste from the leaves of this plant become a serious issue for the cleanliness of the city. Organic solid waste that comes from the falling leaves have the potential to be used as a solid fuel alternative in the form of briquettes when processed appropriately. This study aims to investigate the potential of Cerbera manghas leaves waste to be used as raw material of biomass briquettes with tapioca as a binder, to evaluate the property of the resulted briquettes using ultimate analysis, proximate analysis, and also to find the effect of the composition of tapioca to the heating value of the biomass briquettes. Heating values of five mixtures with various tapioca compositions of $10 \%, 20 \%, 30 \%, 40 \%$, and $50 \%$ were evaluated using an oxygen bomb calorimeter. The experimental results showed that the biomass briquettes made of Cerbera manghas leaves waste can be made using tapioca as a binder. The greater the percentage of the mass of tapioca in the briquettes, the lower heating value generated. Biomass briquettes made of Cerbera manghas leaves waste can be made into a source of sustainable energy with the optimal composition of $90 \%$ waste leaves and $10 \%$ tapioca.
\end{abstract}

Keywords: Biomass, sustainable energy, briquette, Cerbera manghas.

\section{Introduction}

Energy crisis is a concern because of the diminishing natural resources, which are used to power industrial society as a result of a global society demand. These natural resources are in limited supply. While they do occur naturally, it can take hundreds of thousands of years to recover the fuel. The energy crisis occurs because of the growth in fuel consumption rate and population growth. Besides saving this non-renewable energy sources, the search for new alternative energy is needed to fulfill the human needs such as electricity, fuel etc.

Biomass is the most common form of renewable energy, widely used in the third world, but until recently, less in the Western world. The examples of biomass fuel are biodiesel, biogas, agricultural waste, and others. The source of biomass can be produced from agricultural crops and their residues, forestry crops, sea weed, algae, animal residues, industrial residues, municipal solid waste, and sewage [1]. Besides biomass as an alternative energy source, development for substitute of fossil fuel such as biomass is in high demand. An experiment about bioenergy proves that bioenergy have a potential as alternative energy source and the utilization of biomass also increases from time to time [2-6].

Indonesia is one of many developing countries in the world which has many resources of energy such as oil, and coal. Indonesia became top coal exporter in 2014. Besides, Indonesia is also an agrarian country which was evident from the fact that $70 \%$ from 186 million hectares is used to agricultural sector [7]. This condition gives an opportunity to produce biomass alternative energy using agricultural waste. Because of the Indonesian government green policies, every city in Indonesia should plant more trees to minimize global warming and counteract the emission of vehicle pollution.

Trees are the main element in the city park, and they are useful in improving the air quality in densely populated cities such as Surabaya as shown in Figure 1. On the other hand, planting a large number of trees causes a lot of waste from leaves as shown in Figure 2. Government and many communities in Surabaya are facing serious issues with the solid waste leaf from the Cerbera manghas plant. Disposal problems and considerable efforts are being made to reduce the quantities of municipal solid waste.

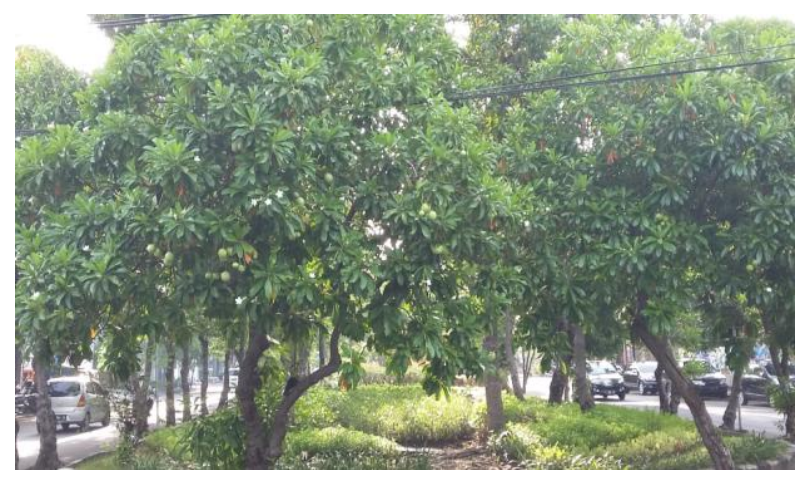

Figure 1. City Park with Cerbera manghas, Surabaya, Indonesia 


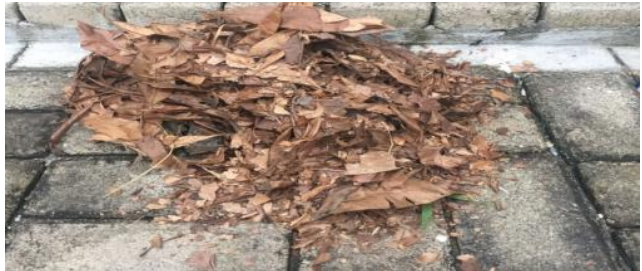

Figure 2. Waste leaves of Cerbera manghas

These Cerbera manghas leaves waste can be used as an alternative energy through the right process. Previously, there was an experiment regarding biodiesel production from Cerbera manghas, and it proves that Cerbera manghas has potential to be an energy source [8]. Biomass solid fuel can be produced from waste, such as almond leaves, sawdust, coco peat, rice husk, sugar cane leaves, and rice straw. Solid fuel briquette geometries have a different properties such as briquette strength. Solid fuel briquettes are an alternative energy known as biomass energy produced from waste product such as botanical waste and wooden waste. Cerbera manghas leaves contain some chemical composition that may be harmful to living creature. i.e, human beings and animals which assure us that Cerbera manghas is a non-edible plant. Other substances found in Cerbera manghas leaves are p-hydroxybenzaldehyde, benzamide, n-hexadecane acid monoglyceride, loliolide, $\beta$-sitosterol, cerberin, neriifolin, cerleaside $\mathrm{A}$, and daucosterol [9-13]. Because of the various substances in the leaves where the properties of the mixture are unknown, it is important to investigate the fundamental properties of biomass briquettes made of Cerbera manghas leaves waste such as proximate, ultimate, heating value, and the effect of tapioca as a binder material.

\section{Experimental Method}

The waste materials used in this study are the leaves of Cerbera manghas which have already fallen from the plant. Collected leaves shown in Figure 3. Once collected, the leaves must be sun dried for three days as shown in Figure 4. Biomass briquettes were made by crushing dried Cerbera manghas waste leaves into the desired particle size $(60$ Mesh), mixing them with tapioca flour as a binder material, and compacting the mixture under pressure.

The measurement of heating value of the biomass briquette from Cerbera manghas leaves waste is done using an oxygen bomb calorimeter as shown in Figure 5. Initially, $100 \%$ of Cerbera manghas leaves, and $100 \%$ tapioca have been measured. All experiments in this paper were performed with mixtures of various tapioca as a binder material from $10 \%$ (90\% composition of Cerbera manghas leaves) to $50 \%$ (50\% composition of Cerbera manghas leaves).

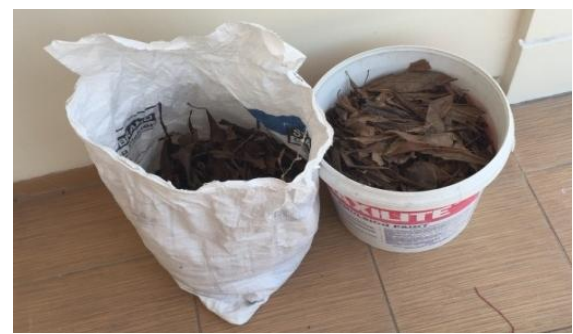

Figure 3. Collecting Cerbera manghas dry leaves

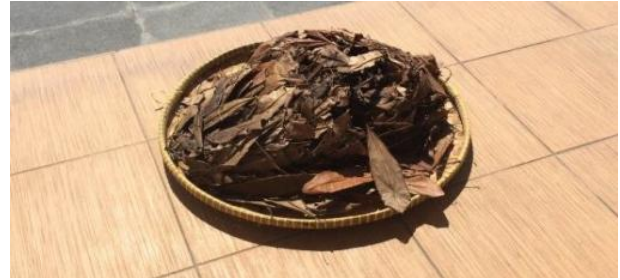

Figure 4. Sun drying Cerbera manghas leaves

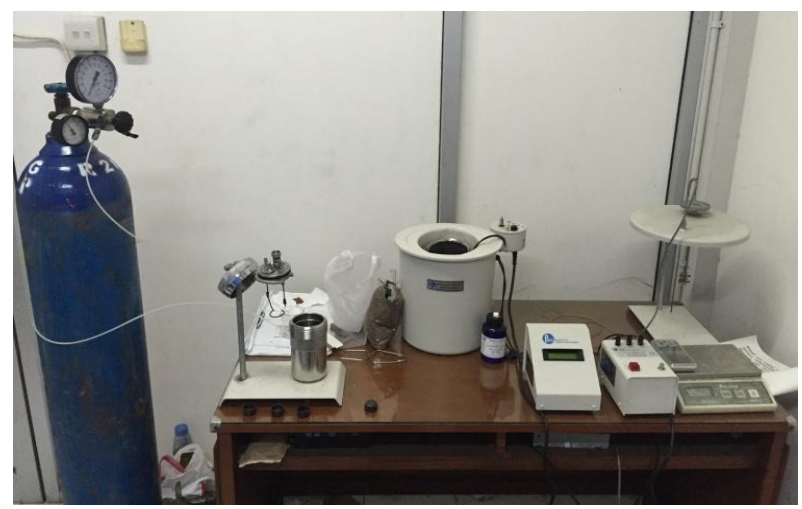

Figure 5. The oxygen bomb calorimeter

\section{Result and Discussion}

Based on the experimental investigation using an oxygen bomb calorimeter, the heating values of $100 \%$ Cerbera manghas leaves were $4287.53 \mathrm{Kcal} / \mathrm{Kg}$ and the heating value of $100 \%$ tapioca as a binder material was $3574.47 \mathrm{Kcal} / \mathrm{Kg}$. The heating value of biomass briquette from Cerbera manghas waste leaves at various composition mixtures are shown in Table 1, and a summary of the results from heating value of Cerbera manghas-tapioca mixtures at various composition are shown Figure 6.

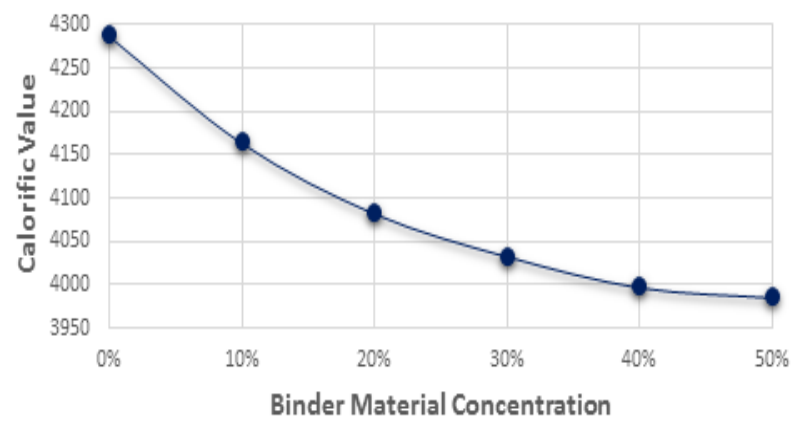

Figure 6. Effect of binder material at various composition of biomass briquette

Table 1. Heating value of biomass briquette from waste leaf Cerbera manghas at various composition

\begin{tabular}{lc}
\hline Biomass Briquette Composition & $\begin{array}{c}\text { Heating Value } \\
\text { (Kcal/Kg) }\end{array}$ \\
\hline 90\% Cerbera manghas and 10\% tapioca mixtures & 4164.00 \\
80\% Cerbera manghas and 20\% tapioca mixtures & 4082.58 \\
70\% Cerbera manghas and 30\% tapioca mixtures & 4033.23 \\
60\% Cerbera manghas and 40\% tapioca mixtures & 3997.44 \\
50\% Cerbera manghas and 50\% tapioca mixtures & 3985.82 \\
\hline
\end{tabular}


The greater amount of tapioca, the lower the heating value of the biomass briquettes from Cerbera manghas leaves. The highest heating value of the biomass briquettes from Cerbera manghas leaves were the biomass briquettes using $90 \%$ Cerbera manghas leaves, and 10\% tapioca mixtures as shown in Figure 6. The 90\% Cerbera manghas and $10 \%$ tapioca mixtures successfully creates a briquette model as shown in Figure 7. The particle size of Cerbera manghas briquettes is 60 Mesh. After the pressing process, briquettes must be dried to reduce the water content. This experiment used room temperature to dry the briquettes.

Tapioca which serves as a binder material, reduces the heating value of the biomass briquette from Cerbera manghas leaves waste. The greater amount of tapioca, the lower the heating value of the briquette. In terms of cost, the most economical composition is also found in $90 \%$ Cerbera manghas leaves, and $10 \%$ tapioca mixtures. It is because the leaves waste cost nothing while the tapioca cost about 0.5 USD $/ \mathrm{kg}$ (the price of tapioca in Indonesia is about 0.5 USD $/ \mathrm{kg}$ in May 2016). The higher the percentage of tapioca in the biomass briquette from Cerbera manghas leaves waste the higher the cost of the briquettes.

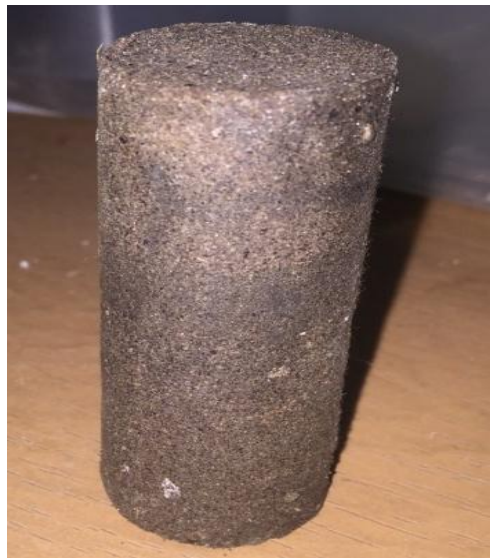

Figure 7. Cerbera manghas leaves briquette

Table 2. Proximate analysis result of Cerbera manghas leaves briquettes

\begin{tabular}{lccc}
\hline \multicolumn{1}{c}{ Parameters } & Unit & Value & Test Method \\
\hline Total Moisture & $\%$ wt & 12.2 & ASTM D 2961-11 \\
Ash Content & $\%$ wt & 8.6 & ASTM D 3174-12 \\
Volatile Matter & $\%$ wt & 66.8 & ASTM D 3175-11 \\
Fixed Carbon & $\%$ wt & 12.4 & ASTM D 3172-13 \\
Total Sulfur & $\%$ wt & 0.19 & ASTM D 4239-14e1 \\
Gross Calorific & Kcal/Kg & 4164 & ASTM D 5865-13 \\
Value & & & \\
\hline
\end{tabular}

Table 3. Ultimate analysis result of Cerbera manghas leaves briquettes

\begin{tabular}{lccl}
\hline \multicolumn{1}{c}{ Parameters } & Unit & Value & \multicolumn{1}{c}{ Test Method } \\
\hline Carbon & $\%$ wt & 40.37 & ASTM D 5373-14 \\
Hydrogen & $\%$ wt & 5.17 & ASTM D 5373-14 \\
Nitrogen & $\%$ wt & 0.45 & ASTM D 5373-14 \\
Sulfur & $\% w t$ & 0.19 & ASTM D 5373-14e1 \\
Oxygen & $\%$ wt & 33.01 & ASTM D 5373-15 \\
\hline
\end{tabular}

The proximate analysis and ultimate analysis have been examined through a laboratory test. The test used ASTM standardization. The total moisture content was examined using ASTM D 2961-11. The ash content was examined using ASTM D 3174-12. Ash, as determined by this test method, is the residue remaining after burning the products. Ash obtained differentiates in composition from the inorganic constituents present in the original product. The volatile matter was examined using ASTM D3175-11. Fixed carbon calculation was examined using ASTM D 3172-13. Total sulfur calculation was examined using ASTM D 4239-14e1. And the gross calorific value calculation was examined using ASTM D 5865-13. The proximate analysis results show total moisture, ash content, volatile matter, fixed carbon, total sulfur, and gross calorific value as shown in Table 2.

The ultimate analysis used to investigate the carbon, hydrogen, oxygen, nitrogen and sulfur concentration on Cerbera manghas leaves briquettes. The examinations of the ultimate analysis were done using ASTM D 5373-14, ASTM D 5373-14e1 and ASTM D 5373-15. The result of ultimate analysis of Cerbera manghas leaves briquettes shown in Table 3.

Cerbera manghas briquette has the highest calorific value compared to sawdust briquette, sugarcane briquette, rice straw briquette, and coconut coir briquette. The calorific values of sawdust briquette, rice straw briquette, sugarcane briquette and coconut coir briquette are $4161.0898 \mathrm{kcal} / \mathrm{kg}$, $3902.9637 \mathrm{kcal} / \mathrm{kg}, 3926.8642 \mathrm{kcal} / \mathrm{kg}$ and $4146 \mathrm{kcal} / \mathrm{kg}$ respectively $[12,14]$.

\section{Conclusion}

Biomass briquette from Cerbera manghas waste leaves is a sustainable energy and tapioca material play a role in the resulted heating value on the biomass briquette from Cerbera manghas leaves waste. The greater the amount of tapioca as a binder material, the lesser the heating value of the briquette, and the higher the cost of the biomass briquette from Cerbera manghas leaves waste. The biomass briquettes have been developed as energy source from Cerbera manghas leaves waste using 90\% Cerbera manghas leaves and $10 \%$ tapioca as the optimal composition.

\section{References}

1. Baskar, C., Baskar, S., and Dhillon, R.S., Biomass Conversion - The Interface of Biotechnology, Chemistry and Materials Science, Springer-Verlag, Berlin Heidelberg (Germany), 2012.

2. Anggono, W., Wardana, I.N.G., Lawes , M., Hughes, K.J., Wahyudi, S., Hamidi, N., and Hayakawa A., Biogas Laminar Burning Velocity and Flammability Characteristics in Spark Ignited Premix Combustion, Journal of Physics Conference Series, 423, Apr 2013, pp. 1-7.

3. Anggono, W., Wardana, I.N.G., Lawes, M., and Hughes, K.J., Effects of Inhibitors on Biogas Laminar Burning Velocity and Flammability Limits in Spark Ignited Premix Combustion, International Journal of Engineering and Technology, 5(6), Jan 2013, pp. 49804987. 
4. Anggono, W., Wardana, I.N.G., Lawes, M., Hughes, K.J., Wahyudi, S., and Hamidi, N., Laminar Burning Characteristics of Biogas-Air Mixtures in Spark Ignited Premix Combustion, Journal of Applied Sciences Research, 8(8), Aug 2012, pp. 4126-4132.

5. Serrano, C., Hernandez, J.J., Mandilas, C., Sheppard, C.G.W., and Woolley, R., Laminar Burning Behaviour of Biomass Gasification-Derived Producer Gas, International Journal of Hydrogen Energy, 33(2), Jan 2008, pp. 851-862.

6. Rosua, J.M. and Pasadas, M., Biomass Potential in Andalusia, from Grapevines, Olives, Fruit Trees and Poplar, for Providing Heating in Homes, Renewable and Sustainable Energy Reviews, 16(6), Aug 2012, pp. 4190-4195.

7. Widiarta, A., Rosyida, I., Gandi, R., and Muswar, H.S., Peasant Empowerment through Social Capital Reinforcement: Road to Sustainable Organic Agriculture Development, Asian Journal of Food and Agro-Industry, 2 (Special Issue), Aug 2009, pp. 297-306.

8. Ong, H.C., Silitonga A.S., Mahlia, T.M.I., Masjuki, H.H., and Chong, W.T., Investigation of Biodiesel Production from Cerbera Manghas Biofuel Sources, Energy Procedia, 61, 2014, pp. 436-439.
9. Raju, C.A.I., Jyothi, K.R., Satya, M., and Praveena, U., Studies on Development of Fuel Briquettes for Household and Industrial Purpose, International Journal of Research in Engineering and Technology, 3(2), Feb 2014, pp. 54-63.

10. Prasityousil, J. and Muenjina, A., Properties of Solid Fuel Briquettes Produced from Rejected Material of Municipal Waste Composting, Procedia Environmental Sciences, 17, 2013, pp. 603-610.

11. Yank, A., Ngadi, M., and Kok, R., Physical Properties of Rice Husk and Bran Briquettes under Low Pressure Densification for Rural Applications, Biomass and Bioenergy, 84, Jan 2016, pp. 22-30.

12. Jittabut, P., Physical and Thermal Properties of Briquette Fuels from Rice Straw and Sugarcane Leaves by Mixing Molasses, Energy Procedia, 79, Nov 2015, pp. 2-9.

13. Zhang, X.P., Pei, Y.H., Liu, M.S., Kang, S.L., and Zhang, J.Q., Chemical Constituents from the Leaves of Cerbera Manghas, Asian Pacific Journal of Tropical Medicine, 3(2), Feb 2010, pp. 109-111.

14. Lela, B., Barišić, M., and Nižetić, S., Cardboard/ Sawdust Briquettes as Biomass Fuel: Physical-Mechanical and Thermal Characteristics, Waste Management, 47(Part B), Jan 2016, pp. 236-245. 